matical mill with an imposing number of figures is sufficiently difficult to eradicate without such examples by teachers !

Apart from a few blemishes of the kind alluded to, the book may still, forty-four years after its first appearance, be recommended as worthy of careful study.

A. E. C.

\section{The International Research Council.}

International Research Council: Constitutive Assembly held at Brussels, July 18 to July 28 , 19r9. Reports of Proceedings. Edited by Sir Arthur Schuster. Pp. iii $+286 . \quad$ (London: Harrison and Sons, I920.) Price Ios. $6 d$.

$\prod \mathrm{H}$ Constitutive Assembly of the International Research Council, which met at Brussels on July i8, I9I9, established for certain subjects new international organisations to replace those existing before the war, and in this volume we have the official text of the statutes there adopted or proposed, as well as the procès-verbaux of the different meetings which were held.

It will be remembered that in October, I9I8, a conference of the scientific academies of the Allied nations was held in London at the invitation of the Royal Society to consider the action which should be taken in regard to international associations; for some had lapsed during the war, and others were unlikely to meet in their old form for some years to come. The resolutions then agreed to were carried further at a second conference which was held at Paris in November of the same year, when the International Research Council was formed, and an executive committee appointed to prepare proposals to be submitted to the Constitutive Assembly at Brussels. The meeting at Brussels formed the third stage in the formation of the new international organisation which had been decided upon in London, and at it the statutes of the International Research Council and of the Unions for Astronomy, for Geodesy and Geophysics, and for Pure and Applied Chemistry were approved.

The legal domicile of the International Research Council is at Brussels, where the general assembly will meet from time to time; but this in no way restricts the Unions, the members of which determine the places of their bureaux and of their periodical meetings as they please. The countries participating in the foundation of the International Research Council are Belgium, Brazil, the United States, France, the United Kingdom, Australia, Canada, New Zealand, South Africa, Greece, Italy, Japan, Poland, Portugal, Rumania, and Serbia, in addition to which the following neutral countries were invited to join the Council : China,
Siam, the Argentine Republic, Chile, Denmark, Spain, Mexico, the Principality of Monaco, Norway, Holland, Sweden, Switzerland, and also Czecho-Slovakia.

Besides the three Unions which were definitely established at the Brussels meeting, proposals were made that several others-mathematics, physics, radiotelegraphy, geology, biology, geography, and bibliography-should be formed, and draft statutes for these were presented in order that the executive committee might communicate them to the National Research Councils of the different countries for the desirability of forming such international unions to be considered. The machinery therefore exists for constituting an international organisation in any branch of science where it will be of service. Several countries have already formally signified their adherence to the International Research Council, and some also to the Unions which have already been formed.

It has been proposed that the draft statutes of the Mathematical Union should be discussed at an international meeting at Strasbourg this autumn, and doubtless representatives of other branches of science will hold similar meetings in due course to consider the desirability of forming unions of their own.

For all such meetings this volume of the proceedings and reports of the Brussels meeting will be of great value, for the general organisation differs from that of earlier associations, and may at first sight seem to be somewhat cumbrous; but a perusal of the documents now published will show that each union can provide itself with the constitution best suited to its own requirements, while conforming at the same time to the essential features of the International Research Council.

\section{Problems of Population.}

(I) Problems of Population and Parenthood. (Being the Second Report of, and the Chief Evidence taken by, the National Birth-rate Commission, 1918-20.) Pp. clxvi +423. (London: Chapman and Hall, Ltd., 1920.) Price 25s. net.

(2) The Social Diseases: Tuberculosis, Syphilis, Alcoholism, Sterility. By Dr. J. Héricourt. Translated, and with a final chapter, by Bernard Miall. Pp. $x+246$. (London: George Routledge and Sons, Ltd.; New York: E. P. Dutton and Co., 1920.) Price $7 s$. $6 d$. net.

(3) The Venereal Problem. By E. T. Burke. Pp. 208. (London: Henry Kimpton, 1919.) Price $7 s .6 d$. net.

(I) $\mathbf{W}^{\text {R. JOSEPH CHAMBERLAIN set a pre- }}$ VI cedent when he gave the name of "Tariff Commission" to a body created by himNO. 2644, VOL. I05] 